\title{
Speech Recognition Technology in Cognitive Translation Studies
}

\author{
Elena V. Chistova* \\ Siberian Federal University \\ 79 Svobodny, Krasnoyarsk, 660041, Russia
}

Received 05.12.2018, received in revised form 28.12.2018, accepted 11.01.2019

\begin{abstract}
Automatic Speech Recognition System (ASRS) is not a new concept; however it is an uncharted piece of technology when applied in the process of translation. Serving as a technology that enables the recognition and translation of spoken language into text by computers, ASRS can optimize the time-consuming translation process. To test the hypothesis a two-cycle experiment was carried out with a group of professional translators attempting to explore the quality of the target text and their time spent translating in a nonstandard setting. Experiment Cycle 1 aims to explore if there would be any difference in cognitive processes of the translator while being an interpreter and expressing orally what is in a written text. Design of Cycle 2 concerns the post-editing stage, and provides information about lexical, grammar, syntax and punctuation corrections made by the translator while adopting the text produced by the $A S R S$. The researcher made use of a user-friendly screen-voice recording software to record every word of the verbalization while sight translation included every change the interpreter made to the rendition; observing the text's linguistics and translation transformations; looking into the justifications of mental operations made by the translator. The results of this study have some implications for the translation process: 1) the syntax analysis shows that in most cases the translators managed to produce natural word order in target sentences; switching to speaking activity from the written text helps to produce the target text at a high level; 2) the lexical analysis finds mistakes in decoding some lexemes with related pronunciation, mistakes in decoding case flexions, using single instead of plural nouns, tautology, functional styles mixture etc., but if the process is regulated, it will be a promising investment in terms of time and effort; 3) the experience of using speech recognition technology seems to reinforce the translators' motivation to upgrade their working tools; 4) ASRS serves as a helpful tool for learners to reflect on their rendition processes and develop a set of measures to remedy the mistakes and shortcomings.
\end{abstract}

Keywords: Cognitive Translation Theory, rendition, empirical translation research, cognitive management problem, retrospective protocol, Computer Aided Translation.

(C) Siberian Federal University. All rights reserved

* Corresponding author E-mail address: echistova@sfu-kras.ru

ORCID 0000-0002-4016-7935

This work is licensed under a Creative Commons Attribution-NonCommercial 4.0 International License (CC BY-NC 4.0). 
Research area: philology.

Citation: Chistova, E.V. (2018). Speech recognition technology in cognitive translation studies. J. Sib. Fed. Univ. Humanit. soc. sci., 12(1), 47-54. DOI: 10.17516/1997-1370-0229.

\section{Introduction}

In recent years, the number of business correspondences, scientific articles and technical documents has grown dramatically to the point where it has become problematic for translators', as the process is time-consuming. This research is devoted to finding ways of improving the translator's work by implanting the up-to-date electronic developments in the translation process.

This problem can be solved in the context of Cognitive Translation Theory (Rojo \& Ibarretxe-Antuñano, 2013). This is a new multidisciplinary research area also named Cognitive Translation Studies (Halverson, 2014), and depends on the humanities (cognitive science, translation theory, psycholinguistics, cultural linguistics, semiotics, education, cognitive terminology studies) and sciences (cognitive psychology, neurophysiology, neuropsychology, ergopsychometry). Cognitive Translation Theory examines the correlative problems between the human's body and brain's cognitive processes and translation cases; the role of the translator's linguistic persona as a knower in decoding the source text and creating the target text; translation rules determined by the cognitive science methods.

Today there are many scientific methods to investigate the mental operations of translators and interpreters. There is a list of the most popular of them: cognitive components method (Gerver, 1997; Gile, 1997; Lambert, 1992; Padilla, Bajo, Padilla, 1999), cognitive correlations method (Dillinger, 1994; Garham \& Oakhill, 1989; Glenberg, Kruley, Langston, 1994; Padilla, Bajo, Padilla, 1999), TAPs - Think Aloud Protocols (Kussmaul \& Tirkkonen-Condit, 1995; Minchenkov, 2007; Tirkkonen-Condit \& Laffling, 1993), introspective and retrospective methods (Alves, Pagano, Da Silva, 2009); keyboard logging (Achkasov, 2010; Alves, Pagano, Da Silva, 2009; Jakobsen \& Jensen, 2008; Jakobsen, 2011); eye-tracking method (Alves, Pagano, Da Silva, 2009; Jakobsen \& Jensen, 2008; Jakobsen, 2011).

The main disadvantage of previous methods is that the experiments are conducted in unnatural social environments, so the results can be wrong or useless. We think that all methods of Cognitive Translation Theory have to be oriented to explore cognitive strategies used by tested translators. What for exactly? To reduce their cognitive load and make it easier for their professional activities. 
It should be noted that the greatest interest of scholars to use the cognitive approach to translation issues has been tracked since 1982, when Gideon Toury compared the mysterious work of the translator's brain with a "black box" (Toury, 1995). Scientists wondered if reconstructing mental processes could contribute to a more efficient translation process. It is more logical, in our view, to put in other questions: How to save translators' time? Is it possible to organize technically-mediated translation to optimize the working process if we understand the cognitive processes of the so called "black box"?

\section{Materials and Methods}

To test the hypothesis the researcher suggests using Automatic Speech Recognition System (ASRS) to improve the translator's performance. What is it? It is a system that makes phonemic decoding of the speech acoustic signal during voice messages pronunciation in freestyle, by any speaker, without taking into account the problematic and the volume of the dictionary. So, the ASRS is aimed to solve specific problems, connected with recognizing natural speech and putting it into the computer format.

In support of using the ASRS for the translator's purpose a two-cycle experiment was carried out. The researcher chose 4 professional translators at the age of 30 to 50 who used to work with the Russian and Chinese languages. The main requirements for the translators were: 1) work experience of no less than 3 years, 2) business sphere translation skills, and 3) sight translation skills.

To answer the question if the ASRS makes the translation activity more efficient, the experiment procedure was divided into 2 cycles: 1) translation process with using ASRS, and 2) post-editing procedure included self-assessment, feedback interviews, and reflection.

During the Experiment cycle 1 the researcher gave the task to translate the Chinese text into Russian. The text consists of 2 pages, about 500-600 characters per page. Each translator simultaneously was reading the text and rendering the translation orally. The researcher made use of a user-friendly screen-voice recording free software to record every word of the verbalization while sight translation included every change and comment the interpreter made to the rendition.

The Experiment cycle 2 concerns exploring the scripts edited by the tested translators. Since this was process-oriented research, it was necessary to hypothesize what was happening in the translators' minds. So, the text's linguistics was observed, 
then the finally edited translation transformations were considered, and the quality of the target text was estimated. Then, the translators were interviewed on their impressions of the experiment setting, post-editing procedure, result satisfaction, and future ideas.

At the stage of reflection we compared the target texts produced by online and offline ASRS. It is worth clarifying that most ASRS are divided into two types: offline and online (Lembersky, Ordan, Wintner, 2012). Offline programs contain more words in vocabulary (up to 500 words) and focus on a particular language (Russian, German, English, etc.). These programs are paid, professional, and of high quality. Online programs are free, but require installations, work only live, so unfortunately we could not get the translation scripts recorded on tape.

\section{Results}

The qualitative and quantitative results of this study have some implications for the translating process. According to the measuring accuracy procedure the researcher fixed $85 \%$ of correct Russian speech recognition. However, the lexical analysis finds mistakes in decoding some lexemes with related pronunciation (cmamb - become instead of статья - article); mistakes in decoding case flexions (клиента, клиенту, клиенте, клиентом); putting single instead of plural nouns (руководитель instead of руководители); tautology (выполнять).

The syntax analysis shows that in $82 \%$ cases the translators managed to produce more natural word orders in Russian sentences that proves low risk of translation interference of the source language. Switching to speaking activity from the written text helps to produce the high level of translation equivalence in the target text. However, the stylistics does not always satisfy the required style that demonstrates functional styles mixture (писать очень много разных статей о проектах instead of вести документацию) еtс.

It must be said that the researcher used both online and offline software to compare the quality of the scripts. It takes no more than 20-30 minutes to record each interpreter. There is a mixture of translating and interpreting activities, so it's difficult to identify. In most cases, the researcher has to interrupt the tested because the program doesn't hurry to read all the voice information. The linguistic script analysis found the advantages of offline systems but there were also a number of technical problems: lack of instructions with plug-ins, the inability to install the software, the complexity of the script with the extraction, etc. 


\section{Discussion}

The experiment goes only in the direction from Chinese to Russian because the quality of reading the Chinese voice information leaves much to be desired. Thus, the Russian-Chinese ASRS needs developing.

The stage of post-editing takes a lot of time, most of the translation process, about 100-130 minutes. It should be mentioned that in a natural environment the translators spend, on the same task, no more than 40-50 minutes working. Firstly, the participants of the experiment were shocked at the many mistakes they have to correct, but after analysis it can be concluded that the procedure is not so time-consuming if the translator knows ASRS's weak spot.

\section{Conclusion}

Taking all these into consideration, the main advantages of using ASRS in the translation process is: a) higher typing speed (up to 350-400 words per a minute); b) the translator is less tired; c) there is no desire to reduce the target text because it is too long to type; d) there is no repetitive stress injury; e) there is less interference from the source language due to code-switching from written to colloquial speech.

However, the disadvantages also should be mentioned: a) delay in reading voice information; b) long-term post-editing; c) ASRS's focus on European languages; d) need sight translation skills.

Despite some disadvantages of translating with help of ASRS three of four of our tested translators desire to use such programs in their future professional activities in order to reduce their cognitive and physical load. Although timeconsuming and still not regulated process they consider it be quite a promising investment with regards to time and effort. The screen-voice recordings serve as a helpful tool for translators to reflect on their rendition processes, to look at themselves critically in hopes to develop a set of measures to remedy the mistakes and shortcomings.

\section{Acknowledgments}

I would like to acknowledge Yang Mingbo, Zhan Yu, Irina Nagibina and Ekaterina Butanaeva, Chinese-Russian translators, who agreed to participate in my experiment and allowed me to interview them at length. I am also grateful to my mentor A.V. Kolmogorova who encouraged me to pursue this topic and spend extra time helping me to achieve a clear structure. 


\section{References}

Achkasov, A.V. (2010). Using the Logging Method in the Translation Studies. In Proceedings of the XXXIX International Philological Conference "Actual Problems of Translation", 13-27. St. Petersburg State University.

Alves, F., Pagano, A., Da Silva, I. (2009). A new window on translators' cognitive activity: methodological issues in the combined use of eye tracking, key logging and retrospective protocols. In Methodology, technology and innovation in translation process research: a tribute to A.L. Jakobsen, 267-291. Copenhagen.

Dillinger, M. (1994). Comprehension during interpreting: What do interpreters know that bilinguals don't? In Bridging the Gap: Empirical Research in Simultaneous Interpretation, 155-189. Amsterdam.

Garham, A., Oakhill, J.V. (1989). The everyday use of anaphoric expressions: implications for the mental models theory of text comprehension. In Models of Cognition: A Review of Cognitive Science, 78-112. Norwood.

Gerver, D. (1974). Simultaneous listening and speaking and retention of prose. In Quarterly Journal of Experimental Psychology, 26 (3), 337-342.

Gile, D. (1997). Conference interpreting as a cognitive management problem. In Cognitive Processes in Translation and Interpreting, 196-214. New Delhi.

Glenberg, A.M., Kruley, P., Langston, W.E. (1994). Analogical processes in comprehension. In Handbook of Psycholinguistics, 609-639. San Diego.

Halverson, S. (2014). Reorienting Translation Studies: Cognitive Approaches and the Centrality of the Translator. In Translation: A Multidisciplinary Approach, pp. 116-140. London.

Jakobsen, A.L., Jensen, K.T.H. (2008). Eye movement behaviour across four different types of reading task. In Looking at eyes: Eye-tracking studies of reading and translation processing, 103-124. Copenhagen.

Jakobsen, A.L. (2011). Tracking translators' keystrokes and eye movements with Translog. In Methods and strategies of process research: Integrative approaches in Translation Studies, 37-55. Amsterdam/Philadelphia.

Kussmaul, P., Tirkkonen-Condit, S. (1995). Think-aloud protocol analysis in translation studies. In TTR: Traduction, Terminologie, Rédaction, 8(1), 177-199.

Lambert, S. (1992). Shadowing. In Meta, 37/2, 263-273.

Lembersky, G., Ordan, N., Wintner, S. (2012). Language Models for Machine Translation: Original vs. Translated Texts. In Computational Linguistics, 38, $4,799-825$. 
Minchenkov, A.G. (2007). Cognition and Heuristics in Translation Studies. Doctoral dissertation, Philology Department, St. Petersburg State University.

Padilla, P., Bajo, M.T., Padilla, F. (1999). Proposal for a Cognitive Theory of Translation and Interpreting. In A Methodology for Future Empirical Research, 61-78. EUT - Edizioni Università di Trieste.

Rojo, A., Ibarretxe-Antuñano, I. (2013). Cognitive Linguistics and Translation Studies: Past, Present and Future. In Cognitive Linguistics and Translation, 3-30. Berlin.

Tirkkonen-Condit, S., Laffling J. (1993). Investigating Translation Strategies. In Recent Trends in Empirical Translation Research, Studies in Languages (pp. 99120). Joensuu.

Toury, G. (1995). Descriptive Translation Studies and Beyond. Amsterdam/ Philadelphia.

\section{Технология распознавания речи в когнитивном переводоведении}

Е.В. Чистова

Сибирский федеральный университет Россия, 660041, Красноярск, пр. Свободный, 79

Система автоматического распознавания речи (ASRS) уже не является новой технологией, однако считается перспективной в контексте переводческой деятельности. Будучи инструментом, позволяющим распознавать и декодировать разговорную речь в письменный формат, ASRS способствует оптимизащии длительного процесса перевода. Для проверки гипотезы был проведен двухэтапный эксперимент с группой профессиональных переводчиков, во время которого проверялось качество переводного текста и потраченное на перевод в нестандартной обстановке время. Экспериментальный ицикл 1 направлен на выявление особенностей когнитивных процессов переводчика, который пытается перевести и синхронно вербализовать письменный тест. Дизайн ичикла 2 относится к этапу постредактирования и представляет собой анализ лексических, грамматических, синтаксических и пунктуационных корректировок переводчика при адаптации текста, подготовленного ASRS. Результаты этого исследования можно изложить следующим образом: 1) синтаксический анализ показывает, что в большинстве случаев переводчикам удалось создать естественньй порядок слов в переводных предложениях, а переключение на устную репрезентацию письменного текста помогает избежать интерференции в переводе; 2) лексический анализ обнаруживает ошибки при декодировании некоторых лексем со схожим произношением, неправильные флексии, замену множественного числа единственным, тавтологию, смешение функциональных стилей и т. д., но если процесс усовершенствовать, 
mо ASRS станет многообещующим ресурсом с точки зрения времени и усилий; 3) опыт использования технологии распознавания речи усиливает мотивацию переводчиков к модернизации рабочего инструментария; 4) ASRS служит полезным инструментом для саморефлексии учащихся и принятия ряда мер по устранению переводческих ошибок и неточностей.

Ключевые слова: переводоведение, когнитивная лингвистика, автоматизированный перевод, репрезентачия, эмпирическое исследование перевода, проблема когнитивного управления, ретроспективный протокол.

Научная специальность: 10.00.00 - филологические науки. 